\title{
PERANCANGAN FILM PENDEK “BUKAN HAK-KU” UNTUK MENANAMKAN NILAI KEJUJURAN PADA ANAK USIA 8-12 TAHUN
}

\author{
Anggoro Dityo Setiawan ${ }^{1}$, Michael Bezaleel ${ }^{2}$ \\ ${ }^{1,2}$ Progdi Desain Komunikasi Visual, Fakultas Teknologi Informasi, Universitas Kristen Satya Wacana \\ 692013020@student.uksw.edu¹, michael.bezaleel@uksw.edu ${ }^{2}$
}

\begin{abstract}
Abstrak
Penelitian ini membahas tentang perancangan film pendek dengan judul "Bukan Hak-Ku" sebagai salah satu media yang dapat digunakan untuk pendidikan karakter pada anak. Pendidikan karakter berisi nilai-nilai moral untuk anak sangat penting untuk dikenalkan sejak usia dini. Salah satu aspek dari nilai-nilai moral dalam pendidikan karakter yaitu kejujuran. Kejujuran merupakan salah satu sifat dasar yang dimiliki manusia dan harus ditanamkan sejak kecil. Salah satu strategi yang dapat digunakan pendidik untuk menanamkan nilai tersebut adalah dengan media audio visual berupa film. Metode yang digunakan pada penelitian ini adalah metode kualitatif dengan tujuan agar penelitian ini dapat mengungkapkan aspek-aspek yang harus ditekankan dalam sebuah film pendek sehingga penanaman nilai kejujuran dapat dilakukan. Film pendek adalah salah satu media pembelajaran baru bagi anak. Orang tua berperan untuk mengarahkan dan membuat anak mengerti dengan latar belakang budaya yang dekat dengan anak dan memudahkan anak untuk memahami alur cerita serta mengimplementasi cerita tersebut dalam kehidupan sehari-hari.
\end{abstract}

Kata Kunci: film, kejujuran, keluarga, moral

\begin{abstract}
This study discusses the design of short films titled Bukan Hak-Ku as one of the media that can be used for character education. Character education containing moral values for children is very important to be introduced from an early age. One of the moral values in character education is honesty. Honesty is one of the basic characteristics possessed by humans and must be delivered since childhood. One strategy that can be used educators to instill these value is with audio visual media such as films. The method used in this study is a qualitative method to reveal aspects that should be emphasized in a short film so as to instill the values of honesty. Short films are one of the new learning media for children. Parents have a role to direct and make children understand the cultural background that is close to the child. The role of parents is also easier for children to understand the story plot and implement it in everyday life.
\end{abstract}

Keyword: family, film, honesty, moral 


\section{PENDAHULUAN}

Sifat jujur termasuk ke dalam salah satu sifat baik yang dimiliki oleh manusia. Orang yang memiliki sifat jujur merupakan orang berbudi mulia dan yang pasti merupakan orang yang baik. Meskipun jujur merupakan sifat dasar manusia, akan tetapi pada kenyataannya masih banyak yang belum memahami makna kata jujur yang sebenarnya. Pengertian jujur dilihat dari segi bahasa adalah mengakui, berkata, atau pun memberi suatu informasi yang sesuai dengan apa yang benar-benar terjadi atau kenyataan.

Jika diartikan secara lengkap, maka jujur merupakan sikap seseorang ketika berhadapan dengan sesuatu atau pun fenomena tertentu dan menceritakan kejadian tersebut tanpa ada perubahan/modifikasi sedikit pun atau benar-benar sesuai dengan realita yang terjadi. Sikap jujur merupakan apa yang keluar dari dalam hati nurani setiap manusia dan bukan merupakan apa yang keluar dari hasil pemikiran yang melibatkan otak dan hawa nafsu. Bangsa Indonesia telah banyak kehilangan karakter kejujurannya. Bangsa Indonesia tidak lagi memiliki kepekaan terhadap orang lain, ketulusan dalam menjalani perintah, kesungguhan dan kejujuran dalam mengemban tugas.

Pendidikan tanpa karakter bukanlah pendidikan. Untuk membangkitkan hal tersebut, dimulai dari mengajarkan karakter yang jujur kepada siswa sejak dini baik di lingkungan keluarga maupun sekolah (Donder, 2015:15). Terlebih lagi bagi siswa sekolah dasar dimana perkembangan pola pikir yang terjadi pada usia 8-12 tahun tersebut sangat menentukan bagaimana karakter anak akan terbangun.

Menurut Kamala London Newton, profesor psikologi dari University of Toledo, Ohio, Amerika Serikat, menggali cerita dari anak itu susah-susah gampang, karena anak-anak penuh imajinasi. Tapi bukan berarti mereka tidak bisa berkata jujur. Anak-anak bisa menceritakan fakta ketika mereka berkata-kata tanpa dipaksa. Hal itu perlu disadari para orang tua, terutama saat menggali informasi menyangkut keselamatan anak, misalnya, dari kekerasan dan pelecehan seksual. Sayangnya, menurut Newton, banyak orang dewasa lalai menyadari bahwa pikiran anak mudah tercampur-aduk antara satu kejadian dan kejadian lain plus imajinasi.

Cara menggali informasi yang salah membawa anak pada ingatan palsu, bukan kejadian sebenarnya. Reza Indragiri Amriel, psikolog forensik menyatakan bahwa hal itu sesuai dengan Undang-Undang Perlindungan Anak. Bahwa anak pantas didengar pendapatnya. Anak pantang diajukan pertanyaan berulang, akan muncul persepsi bahwa anak harus memberi jawaban sesuai dengan kehendak penanyanya. Terakhir, anak sebaiknya dimintai keterangan dalam suasana yang rileks.

Newton mengatakan jawaban terjujur anak adalah pernyataan yang spontan, datang dari mulut anak sendiri tanpa harus dicecar. Memang, dia mengakui, ada anak yang kesulitan membeberkan peristiwa buruk sehingga memilih diam. Tapi bukan berarti mereka harus dipaksa berbicara (Sutriyanto, 2016). 
Keluarga menjadi awal memupuk dan menanamkan sikap kejujuran dari usia. Pemupukan tersebut bertujuan untuk mempersiapkan mereka (pelajar) agar siap secara mental agar benar-benar jujur dalam melakukan apapun. Oleh karena itu peranan keluarga sebagai salah satu media yang dekat dengan anak diharapkan mempunyai waktu yang lebih panjang untuk mengajarkan kejujuran di bandingkan sekolah dan teman. Salah satu penelitian menyatakan bahwa anak usia 4 tahun kecerdasannya sudah mencapai $50 \%$ dan usia 8 tahun tingkat kecerdasannya sudah mencapai $80 \%$ seperti yang diungkapkan oleh Direktur Pendidikan Anak Usia Dini (PAUD) Depdiknas, Dr. Gautama. Inilah pentingnya peranan orang tua yang kelak menentukan kejujuran (Suyanto, 2005: 6).

Film adalah hasil kaya seni yang dibuat untuk menyampaikan informasi, media massa, media komunikasi, media hiburan, pendidikan dan pemasaran suatu produk kepada khalayak umum melalui sebuah cerita. Istilah perfilman merujuk kepada pemahaman keseluruhan proses yang meliputi persiapan, perencanaan, pelaksanaan, dan pengawasan penyampaian pesan. Film adalah gambar-hidup yang juga sering disebut movie. Film, secara kolektif, sering disebut sinema. Sinema itu sendiri bersumber dari kata kinematik atau gerak. Film juga sebenarnya merupakan lapisan-lapisan cairan selulosa, biasa dikenal di dunia para sineas sebagai seluloid (Nugroho, 1995: 77).

Pengertian secara harafiah film (sinema) adalah Cinemathographie yang berasal dari Cinema dan tho sama dengan phytos (cahaya) dan graphie sama dengan grhap (tulisan sama dengan gambar sama dengan citra), jadi pengertiannya adalah melukis gerak dengan cahaya. Agar kita dapat melukis gerak dengan cahaya, kita harus menggunakan alat khusus, yang biasa kita sebut dengan kamera (Ayona, 2010).

Seiring dengan adanya teknologi yang semakin maju dan berkembang informasi yang disampaikan tidak hanya dapat disampaikan melalui surat kabar, poster, dan audio visual. Untuk itu diharapkan dengan adanya audio visual yang mencakup beberapa aspek di dalamnya dapat digunakan sebagai sarana penyampaian pesan terhadap khalayak. Di dalam konteks ini audio visual yang akan digunakan untuk menyampaikan pesan atau informasi adalah film fiksi yang dibuat secara serial untuk memberikan contoh kepada anak dengan media film fiksi melalui peran orang tua.

Penelitian dengan judul "Perancangan Media Pembelajaran Audio Visual Terhadap Pembelajaran Lompat Jauh Pada Siswa Kelas IV SDN GROBOGAN 04 Kabupaten Grobogan Tahun Ajaran 2012/2013 Studi Kasus : Kabupaten Grobogan" menyatakan bahwa penggunaan media audio visual untuk menyampaikan proses belajar mengajar dengan media yang lebih menarik untuk meningkatkan minat anak dalam proses belajar dan pesan yang akan disampaikanlebih mudah diterima dan dipahami. Salah satu media yang dapat menyampaikan informasi adalah film, karena melalui film pemirsa tidak hanya mendengar audio tetapi juga melihat secara visualisasi dalam bentuk sebuah video atau film (Bachtiar, 2013). Penelitian lain dengan judul "Pendidikan Karakter Disiplin dan Kejujuran Anak Pada Keluarga Polisi (Studi Kasus di Aspolres Sragen Mageru RT 03/RW II Sragen Tengah Kecamatan Sragen Kabupaten Sragen Tahun 2013)" 
menyimpulkan bahwa peran keluarga dalam mendidik anak sangatlah penting karena seringkali perhatian orang tua yang kurang adalah salah satu faktor penghambat seorang anak untuk memiliki dan menyadari nilai-nilai moral, maka anak akan tahu dan mengerti setelah mereka merasa dekat dengan orang tuanya yang mengajarkan tentang pendidikan moral (Sumarsih, 2013).

Penanaman nilai-nilai moral dalam mendukung tercapainya tujuan pendidikan harus dimulai dari tingkatan yang paling dasar yaitu tingkatan keluarga. Sosok orang tua (ayah dan ibu) merupakan individu yang bertanggung jawab terhadap pendidikan nilai-nilai moral dalam keluarga. Sementara itu metode yang dikembangkan oleh keluarga pun sudah saatnya disesuaikan dengan dinamika perubahan masyarakat. Generasi sekarang anak lebih kesepian dan pemurung, lebih beringas, kurang memiliki etika, mudah cemas, gugup dan lebih impulsif. Dari pernyataan tersebut secara kasat mata dapat dengan mudah kita tangkap dalam lingkungan kita, terutama bagi mereka yang hidup di kotakota besar, seperti Jakarta, Surabaya, Bandung, dan lain sebagainya. Kondisi yang memprihatinkan adalah gejala-gejala dan dampaknya sudah mulai merembet ke daerah kota-kota kecil bahkan sampai ke pedesaan (Nugroho \& Yeni, 2006).

Penanaman karakter kejujuran bagi anak sangatlah penting untuk dikembangkan pada anak usia dini. Pembentukan karakter sebaiknya dilakukan sejak usia dini dengan memberikan contoh yang baik dan positif. Penanaman hal yang baik dan positif akan membentuk karakter anak tersebut. Pihak yang berperan dalam penanaman karakter pada anak usia dini antara lain adalah orang tua, guru, serta orang dewasa yang berada di sekitar anak tersebut. Salah satu karakter yang perlu ditanamkan pada anak usia dini adalah kejujuran. Penanaman karakter pada anak usia dini dilakukan melalui keteladanan dan kebiasaan. Anak selanjutnya dapat mempraktikkan kebiasaan yang bersifat baik dan positif dalam kehidupan sehari-hari (Heinich, 2002).

Bagi para orang tua di Jawa sendiri dalam mengajarkan pendidikan karakter kepada anak-anaknya mereka tidak hanya memberikan konsep kepada anak-anaknya tentang karakter apa dan mana yang dianggap sesuai oleh masyarakatnya, tetapi juga berusaha untuk menjalankannya. Sementara itu, terkait dengan bagaimana keluarga menerapkan pola asuh terhadap anaknya akan terkait erat dengan bagaimana budaya di sekitarnya. Hal ini mengingat bahwa orientasi nilai budaya akan mempengaruhi bagaimana kehidupan seseorang. Bagi orang Jawa, maka budaya yang dominan adalah budaya Jawa, budaya yang sejak kecil mereka kenal. Dengan begitu, bagi orang Jawa bagaimana mereka mendidik karakter anak tentunya akan disesuaikan dengan budaya yang mereka yakini, yaitu budaya Jawa (Wibowo, 1997).

Media audio visual adalah media penyampaian informasi yang memiliki karakteristik audio (suara) dan visual (gambar). Jenis media ini mempunyai kemampuan yang lebih baik karena meliputi kedua karakter tersebut. Selanjutnya media audio visual dibagi menjadi dua yaitu (1) Audio visual diam, yaitu media yang menampilkan suara dan gambar diam seperti film bingkai suara(sound slide), film bingkai suara dan cetak suara. 
(2) Audio visual gerak, yaitu media yang dapat menampilkan unsur suara dan gambar gerak seperti film suara dan video cassete (Nugroho \& Yeni, 2006).

Sumber belajar tersebut diantaranya ada yang dimanfaatkan seperti penggunaan di pasar, lapangan, terminal, masjid dan lain sebagainya serta ada pula sumber belajar yang dirancang seperti dalam media buku panduan, Lembar Kerja Siswa (LKS), video pendidikan, buku cerita, novel, dan film-film pendidikan. Diantara sumber-sumber belajar tersebut salah satu yang dapat digunakan adalah film. Namun tentu tidak semua film bisa menjadi media pendidikan dan sumber belajar. Film yang bisa menjadi media pendidikan adalah yang memuat nilai-nilai cerita yang mendidik manusia secara menyeluruh. Sedangkan cerita yang baik adalah cerita yang mampu mendidik akal budi, imajinasi dan etika seseorang serta mengembangkan potensi pengetahuan yang mendidik. Seperti halnya contoh film "Guruku" karya Dean Gunawan sangat sesuai untuk anak-anak dalam menggambarkan bagaimana menanamkan nilai-nilai karakter kepada anak-anak. Seperti halnya mendidik anak agar memiliki sifat jujur, adil, pemberani, dan bertanggung jawab (Irawan, 2014).

"For us, the most importance of all art, is cinema", pernyataan itu dilandasi oleh pengertian bahwa sinema dapat berfungsi sebagai guru sekaligus propaganda. Fungsi sinema sebagai sarana edukatif kultural hanyalah salah satu fungsi kultural sinema Indonesia. Namun dalam ruang lingkup kebijakan mencerdaskan kehidupan bangsa, sinema sebagai sarana edukatif kultural tampaknya perlu kita kaji lebih mendalam. Film sebagai salah satu media massa memiliki pengaruh yang sangat besar dalam perkembangan wawasan dan pembentukan persepsi masyarakat sehingga pada gilirannya akan dapat berpengaruh pada perilaku mereka (Sofiah, 2012: 212). Seperti halnya siaran televisi, tujuan khalayak menonton film terutama adalah ingin memperoleh hiburan. Akan tetapi dalam film dapat terkandung unsur fungsi informatif dan edukatif ataupun persuasif. Fungsi edukasi dapat tercapai apabila film nasional memproduksi film-film sejarah yang objektif, atau film dokumenter dan film yang diangkat dari kehidupan sehari-hari yang berimbang (Ardianto, 2015).

Penelitian ini akan membahas mengenai perancangan film pendek untuk pendidikan karakter. Film tersebut menekankan pada nilai moral pada hal kejujuran dengan target anak usia 8-12 tahun. Di samping itu, film pendek tersebut juga menekankan pada peran orang tua dalam proses penanaman kejujuran pada anak sehingga diharapkan film pendek ini dapat menjadi film keluarga yang dapat ditonton bersama antara orang tua dan anak. Film pendek tersebut juga diharapkan dapat menjadi media yang menarik untuk menanamkan kejujuran bagi anak usia 8-12 tahun.

\section{METODE PENELITIAN}

Metode yang digunakan dalam perancangan menggunakan metode kualitatif. Metode kualitatif bersifat fleksibel dan dapat berubah-ubah sesuai kondisi lapangan dengan pengambilan data, metode kualitatif merupakan metode pengambilan hasil langsung dari narasumber yang berupa wawancara (Noval, 2015). Sedangkan strategi yang digunakan dalam penelitian ini linear strategy atau strategi garis lurus yang menetapkan 
urutan logis pada tahapan yang sederhana dan relatif mudah dipahami komponennya (Jonathan dan Lubis, 2007). Tahapan tersebut dapat dilihat pada Gambar 1.

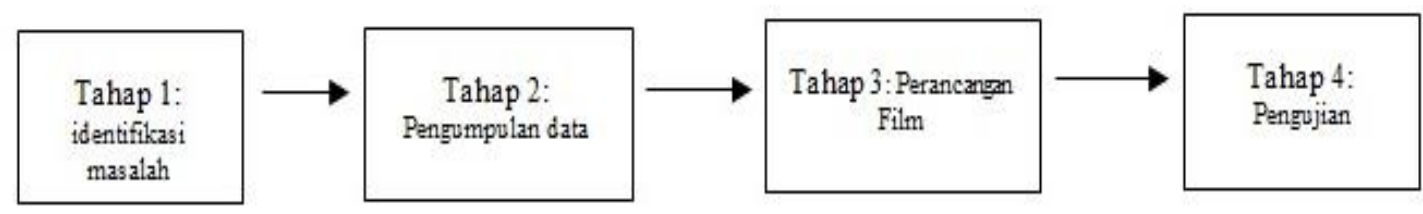

Gambar 1. Bagan strategi linier

Tahap 1 yaitu identifikasi masalah merupakan suatu tahap permulaan dari penguasaan masalah dimana objek dalam suatu jalinan tertentu dapat kenali sebagai suatu permasalahan, tujuan identifikasi masalah agar pembaca mendapatkan sejumlah masalah yang berhubungan dengan judul penelitian (Effendy, 1998:220). Identifikasi masalah dilakukan melalui pengamatan lapangan dan wawancara untuk mendapatkan.

Berdasarkan pengamatan lapangan, diidentifikasi bahwa banyak orang tua yang sudah terlalu sibuk dengan urusan pekerjaan mereka sehingga lupa akan tanggung jawab untuk mendidik anaknya di lingkungan keluarga. Padahal pendidikan moral tidak hanya diberikan di lingkungan pendidikan formal seperti di sekolah saja namun juga melalui peran orang-orang terdekat dan terlebih lagi peran keluarga serta lingkungan sosial.

Di samping melakukan pengamatan lapangan, dilakukan pula wawancara kepada Kasi Kurikulum dan Pengendalian Mutu Dinas Pendidikan Pemuda dan Olahraga Kota Salatiga yaitu Ibu Niken Widagdarini untuk mengetahui bagaimana kurikulum yang berlaku di sekolah dapat memfasilitasi penanaman nilai-nilai kejujuran pada anak. Berdasarkan hasil wawancara tersebut, pendidik atau pengajar memberi pemahaman yang lebih dalam mengenai penerapan etika dan moral, termasuk kejujuran, dalam mata pelajaran di sekolah sesuai dengan kurikulum yang ada. Namun, hal tersebut harus didukung juga dengan pengimplementasian secara langsung dalam kehidupan sehari-hari sehingga perlu adanya peran keluarga.

Tahap 2 yaitu pengumpulan data dilakukan melalui wawancara langsung kepada pihakpihak terkait yaitu:

1. Wawancara pertama dilakukan kepada Kasi Kurikulum dan Pengendalian Mutu Dinas Pendidikan Pemuda dan Olahraga Kota Salatiga, Ibu Niken Widagdarini, mengenai peran pendidikan formal dalam pendidikan karakter. Hasil wawancara tersebut adalah penanaman pendidikan karakter terutama dalam hal kejujuran dimulai pada tahap usia dini melalui suatu pengenalan yang menjadi kebiasaan kemudian melekat menjadi suatu budaya. Beberapa materi pembelajaran yang diajarkan mencakup dalam semua mata pelajaran dimana nilai-nilai kedisiplinan, kejujuran, kepedulian terhadap lingkungan, dan setia kawan sudah termasuk didalamnya. Pentingnya pengajaran tentang nilai moral sejak usia dini adalah diharapkan anak mau berperilaku jujur dan berani mengakui kesalahan. 
2. Wawancara kedua dilakukan kepada Ibu Sri Munawaroh selaku guru mata pelajaran terkait sekaligus Kepala Sekolah SDN Cebongan 3 Salatiga untuk mendapatkan informasi mengenai cara penyampaian materi pembelajaran nilai moral khususnya dalam aspek kejujuran. Hasil wawancara tersebut adalah selama ini materi pembelajaran yang ada hanya sedikit yang menyangkut nilai moral didalamnya. Untuk itu, pihak sekolah mencoba untuk menerapkannya di dalam pembelajaran dalam bentuk kantin kejujuran. Di samping itu, selama ini siswa hanya mendapatkan pemahaman mengenai kejujuran melalui buku cetak. Dengan adanya sebuah rancangan film pendek, maka menjadi daya tarik untuk membantu siswa dalam memahami materi yang disampaikan. Film juga dapat memunculkan pola pikir yang baru bagi siswa dalam bersikap jujur.

3. Wawancara juga dilakukan kepada profesor dalam bidang psikologi yaitu Profesor Sutarto Wijono dari Fakultas Psikologi UKSW Salatiga untuk mengetahui dampak psikis dan psikologis anak terhadap suatu pendidikan karakter melalui lingkungan keluarga. Dari hasil wawancara tersebut, Profesor Sutarto menyatakan bahwa anak akan merasa lebih senang dan bahagia ketika berada dilingkungan keluarga. Anak juga akan merasa lebih nyaman ketika dididik bersama keluarga. Ketika peran orang tua memberikan bimbingan yang tepat dan saling mengisi suatu interaksi maka akan mencapai suatu hubungan yang dinamis antara anak dan orang tua. Saling mendukung, saling mendengarkan, saling mengasihi secara total, dan mengarahkan pola pikir dalam proses perkembangan anak akan menjadi lebih baik. Film edukatif dan kreatif akan mengajak anak untuk berkembang dan memiliki pemikiran yang terbuka asalkan melalui suatu bimbingan orang tua. Karena sifat anak adalah meniru, maka tayangannya pun harus menunjukan dan mengajarkan suatu hal yang mendidik. Nilai-nilai kehidupan sangat berharga untuk bekal kehidupan mereka yang diiringi dengan peran orang tua dan komuikasi yang baik, karena pola asuh juga mempengaruhi sifat dan karakter setiap anak yang didik.

4. Wawancara yang ke empat di lakukan kepada Bapak Novan Yoga selaku orang tua untuk mengetahui cara mengasuh, mengajarkan kejujuran, dan dampak anak yang dididik dalam suatu lingkungan keluarga. Berdasarkan wawancara tersebut didapatkan hasil terdapat beberapa hal umum yang dilakukan oleh orang tua untuk mengajarkan kejujuran pada anak di lingkungan keluarga. Orang tua memberikan contoh perilaku sehari-hari yang sederhana dan mudah dimengerti oleh anak serta memiliki arti yang mudah dipahami oleh anak seperti halnya memberikan sebuah janji dan orang tua menepatinya. Orang tua juga dapat memberikan reward ketika anak melakukan kejujuran serta berani mengakui kesalahannya. Selama ini orang tua memang jarang mengajarkan kejujuran dengan media film namun Bapak Novan Yoga berharap bahwa terdapat film yang dapat mengangkat tentang kejujuran dan memiliki setting keluarga serta bercerita dari lingkungan yang dekat dengan anak.

Tahap 3 yaitu tahap perancangan yang dilakukan dalam film serial terdiri dari tiga proses yaitu pra produksi, produksi dan pasca produksi. Proses perancangan dapat dilihat pada Gambar 2. 


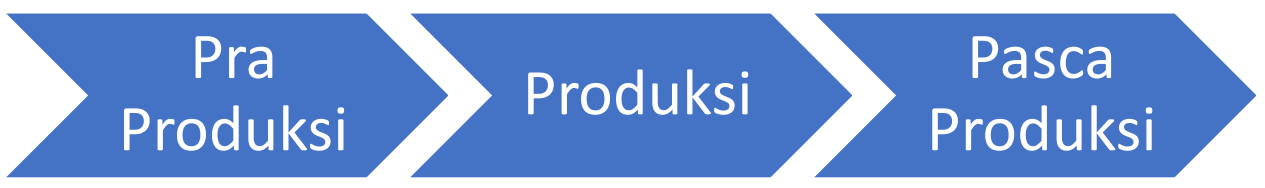

Gambar 2. Bagan perancangan film

Proses pertama adalah proses pra produksi. Proses ini merupakan proses merumuskan ide dan konsep film, pembuatan treatment, dan storyboard. Proses tersebut akan dilanjutkan dengan proses produksi dimana pada proses tersebut, akan dilakukan pengambilan gambar yang nantinya akan membentuk sebuah film yang diinginkan. Proses yang terakhir adalah proses pasca produksi. Proses pasca produksi merupakan sebuah proses dimana hasil pengambilan gambar akan dipilih dan disatukan menjadi sebuah rangkaian video yang utuh. Selain itu dilakukan juga penambahan audio dan elemen-elemen lainnya termasuk pemberian kesan dalam film melalui grading sebelum dilakukan rendering untuk menghasilkan sebuah film pendek yang siap tayang.

Tahap 4 yaitu pengujian. Setelah film pendek siap untuk ditayangkan, akan dilakukan tahap pengujian. Tahap pengujian ini dilakukan kepada siswa Sekolah Dasar, orang tua, dan perwakilan dari Dinas Pendidikan Pemuda dan Olahraga Kota Salatiga. Pengujian ini dilakukan untuk mengetahui bagaimana film pendek tersebut memiliki peran sebagai bagian dari media pendidikan nilai kejujuran bagi anak.

\section{HASIL DAN PEMBAHASAN}

Konsep film ini mengangkat tentang kehidupan sehari-hari, terutama dampak berbuat kebaikan dan dampak dari kejujuran. Film ini diberi judul "Bukan Hak-Ku". Pesan yang ingin disampaikan melalui film ini adalah kejujuran membawa dampak yang baik bagi diri sendiri maupun lingkungan sekitar. Kejujuran tidak selalu menyenangkan namun selalu membawa kebaikan. Berdasarkan konsep film tersebut disusunlah sebuah treatment yang akan memandu penonton untuk memahami film dan juga pesan yang ingin disampaikan melalui film tersebut.

Karakter utama yang ada dalam film ini adalah Krisna. Krisna merupakan seorang anak usia 12 tahun yang memiliki banyak teman bermain di sekitar rumahnya. Ibu Krisna merupakan seorang ibu rumah tangga yang sehari-hari mengurus rumah tangga keluarganya. Bapak Krisna adalah seorang karyawan swasta yang bekerja 5 hari seminggu. Krisna sedang menjalani pendidikan di jenjang sekolah dasar. Krisna memiliki teman-teman sebaya antara lain Robi, Ivan, dan Banu.

Cerita dimulai dengan latar belakang anak-anak yang berkumpul dan bermain mobil remote control serta berbagai mainan lainnya. Nampaklah seorang anak bernama Krisna datang dari kejauhan untuk ikut bergabung dan bermain. Sementara itu, Ibu Krisna yang hendak ke warung untuk membeli sembako terkejut karena uang belanjanya di dompet menjadi berkurang dari yang seharusnya. Ibu Krisna mengira uangnya sudah diambil oleh suaminya sehingga terjadi kesalahpahaman antara Ayah dan Ibu Krisna tersebut. Ternyata bukan Ayah Krisna yang mengambil uang itu dan mereka mengira mungkin 
Krisna yang mengambil uang itu. Maka, sesampainya di rumah, Ayah Krisna bertanya dan memarahi Krisna.

Di hari yang lain, Krisna sedang bermain di rumah bersama teman-temanya. Salah seorang teman Krisna yaitu Robi ingin menumpang ke kamar mandi Krisna. Tiba-tiba Ibu Krisna pulang karena ada sesuatu yang tertinggal dan segera masuk ke rumah. Saat lbu Krisna masuk ke dalam rumah, terlihat sepasang tangan milik Robi yang membuka-buka tumpukan buku dan sedang mencari sesuatu. Ibu Krisna sangat kaget karena ada Robi yang seperti hendak mencuri sesuatu. Kemudian, Ibu Krisna membawa Robi ke rumah orang tua Robi untuk bertemu dengan Ibu Robi. Krisna dan teman-teman yang lain bingung kenapa Ibu Krisna marah sambil membawa Robi ke arah rumah Robi sehingga Krisna lari menyusul mereka. Sesampainya di rumah orang tua Robi, Ibu Robi marahmarah kepada Robi. Namun Ibu Krisna memaafkan dan meminta untuk mengawasi Robi agar tidak mengulangi perbuatan tersebut. Ibu Krisna pun pulang ke rumahnya. Sesampainya di rumah, Ibu Krisna dan menjelaskan apa yang terjadi kepada Ayah Krisna. Krisna dipanggil ayah dan ibunya untuk duduk bersama dan diberikan hadiah sebagai bentuk reward karena selama ini Krisna adalah anak yang jujur dan patuh kepada ayah dan ibunya.

Treatment disusun berdasarkan hasil riset awal baik langsung maupun dengan wawancara dan berdasarkan rumusan ide dalam bentuk film statement yang diuraikan secara deskriptif tentang bagaimana rangkaian film pendek dalam penelitian ini. Setelah merancang treatment dilanjutkan pembuatan storyboard. Storyboard merupakan rangkaian gambar ilustrasi yang berusaha menerjemahkan adegan-adegan yang telah dirumuskan didalam skenario. Didalam sebuah storyboard yang dihasilkan dapat memuat informasi mengenai pelaku, lokasi, properti maupun sudut pengambilan gambar [Syaiful, 2015]. Storyboard dapat dilihat pada Gambar 3.

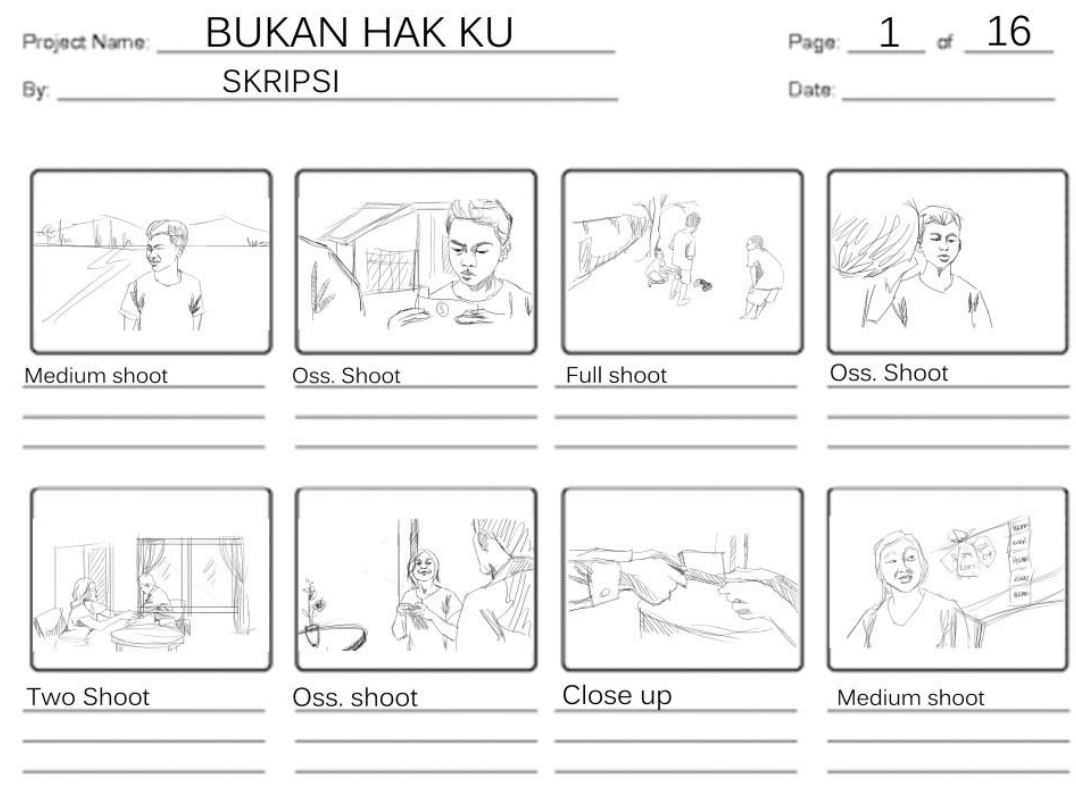

Gambar 3. Storyboard Bukan Hak-Ku [Sumber: Dokumentasi penulis] 
Tahap selanjutnya adalah tahap produksi, yaitu video live action, pada tahap ini yang dilakukan adalah proses shooting di area kota Salatiga dengan talent maupun hanya pengambilan footage dengan mengikuti konsep seperti pada treatment. Proses pembuatan film serial ini menggunakan kamera untuk menghasilkan gambar yang baik serta didukung dengan peralatan pendukung kamera berupa lensa, sound recorder, tripod, dan lain-lain.

Pasca produksi adalah proses terakhir dari ketiga tahapan dalam pembuatan sebuah film. Pasca produksi meliputi tiga proses, yaitu proses offline editing, online editing dan mixing. Offline editing merupakan proses menata gambar sesuai dengan skenario dan urutan shot yang telah ditentukan. Dari semua hasil produksi dilakukan review satu persatu dan dianalisa sesuai kebutuhan video. Setelah didapat bagian gambar yang sesuai lalu disusun pada timeline software editing video sesuai urutan scene yang telah ditentukan. Dalam proses ini dilakukan penambahan efek-efek seperti efek transisi, dan efek-efek lainnya sesuai dengan kebutuhan. Dalam tahap ini juga dilakukan grading dan grading yang digunakan warna merah karena terasa hangat dan bertujuan supaya film mendapat kesan seperti yang natural dapat dilihat pada Gambar 4.

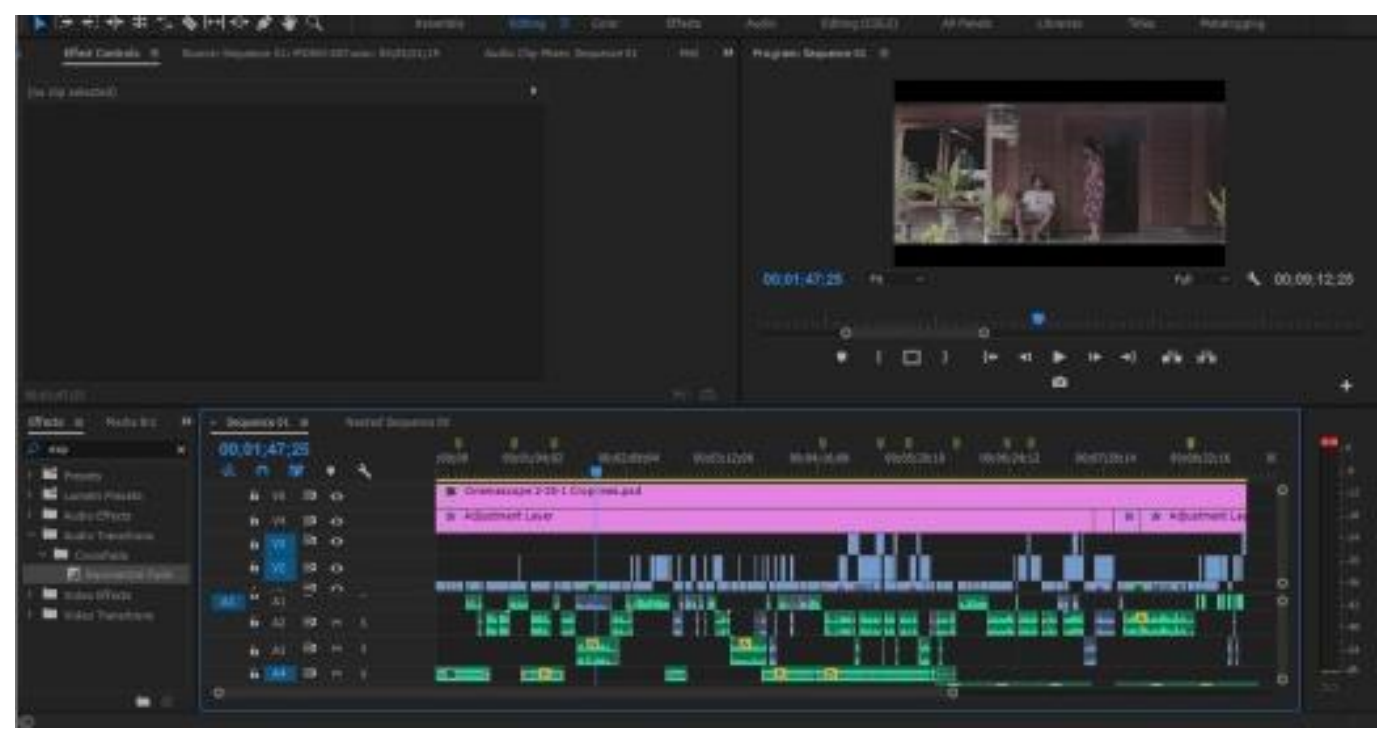

Gambar 4. Offline editing

[Sumber: Dokumentasi penulis]

Setelah online editing selesai maka dilakukan proses mixing yaitu penggabungan dan penyelarasan antara visual dan audio agar menjadi kesatuan yang utuh. Dalam tahap ini pengaturan audio antara audio dan musik latar diatur agar tidak saling mengganggu. Dapat dilihat pada gambar 5. 


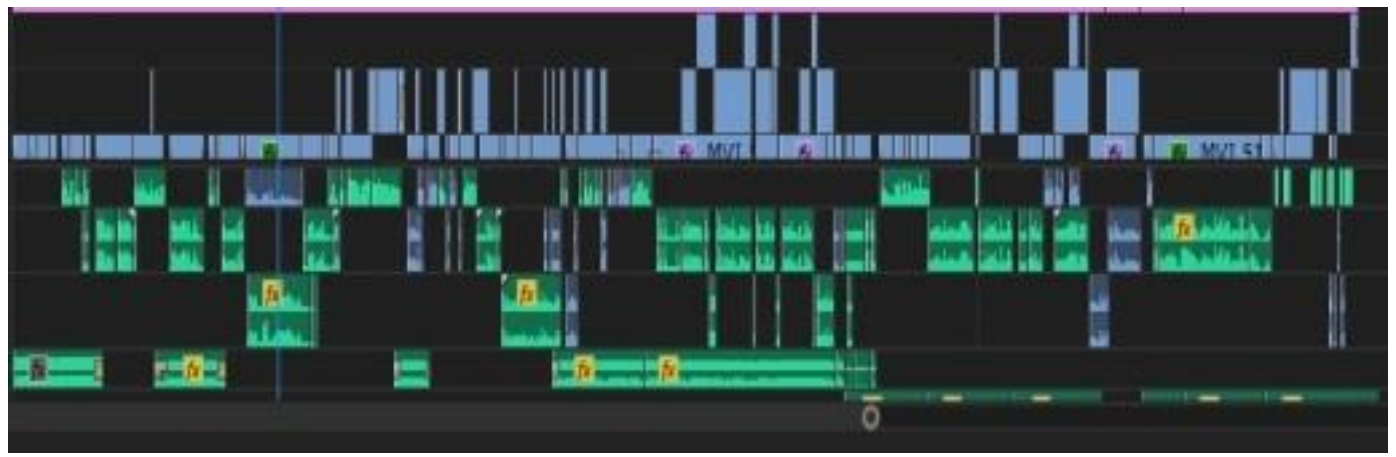

Gambar 5. Mixing

[Sumber: Dokumentasi penulis]

Film pendek ini berisikan informasi tentang sebuah kejujuran seorang anak yang dituduh mencuri uang orang tuanya. Dengan menjunjung pentingnya suatu nilai moral khususnya kejujuran dalam film pendek yang berjudul "Bukan Hak-Ku" menjadikan suatu landasan dalam kehidupan sehari-hari. Potongan adegan yang ada dalam film dapat dilihat pada Gambar 6.

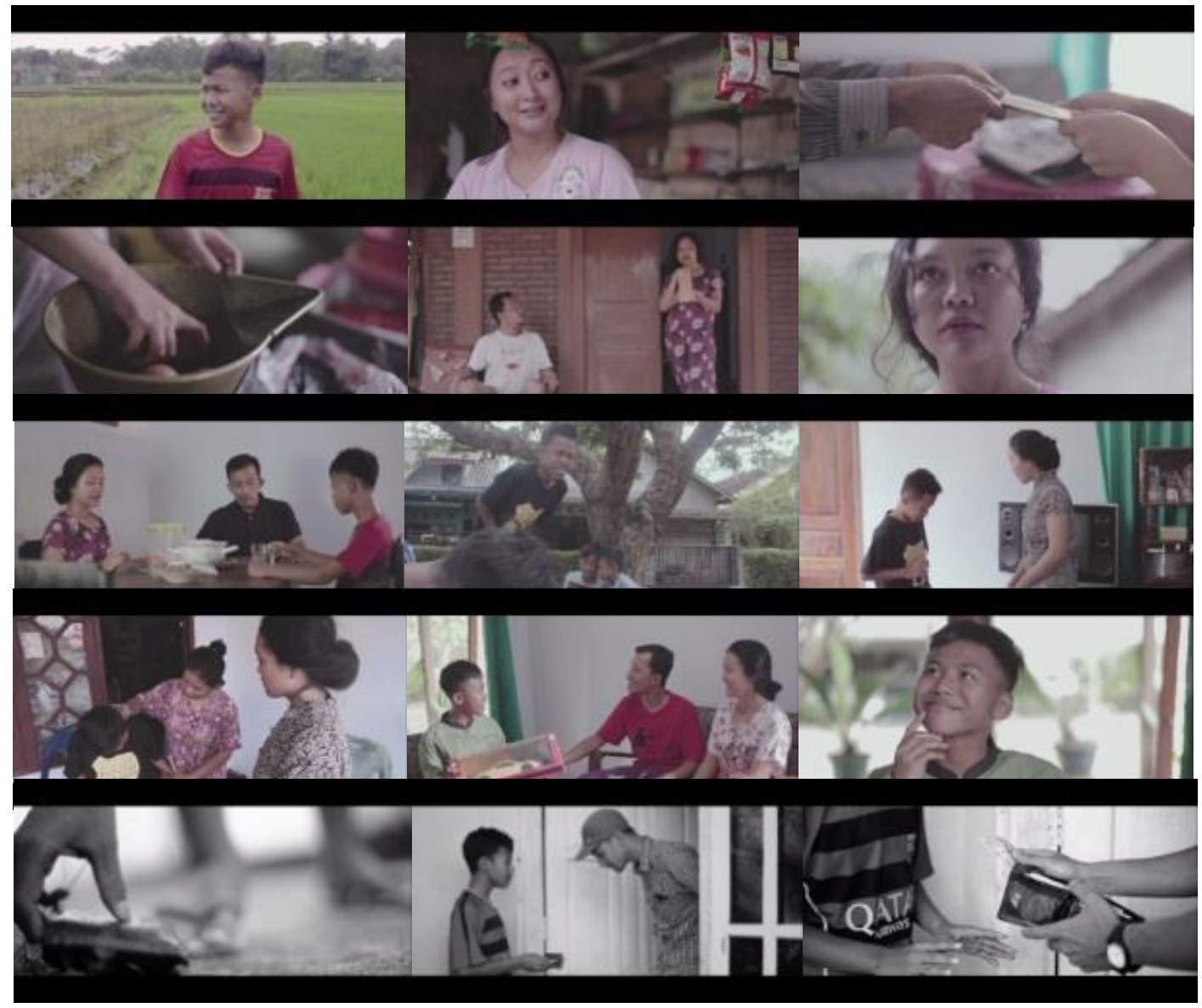

Gambar 6. Potongan adegan film.

[Sumber: Dokumentasi penulis] 
Pada hasil akhir film pendek ini tentang pendidikan karakter khususnya dalam aspek kejujuran akan diunggah dan dibagikan melalui media sosial agar penyebarannya lebih luas. Selain itu film pendek ini akan dibagikan dalam bentuk Compact Disc kepada Dinas Pendidikan Pemuda dan Olahraga Kota Salatiga serta sekolah-sekolah dasar di Salatiga dan sekitarnya.

Gambar 7 dan gambar 8 berikut ini merupakan pengimplementasian film pendek yang berjudul "Bukan Hak-Ku" pada media sosial maupun dalam bentuk compact disc.

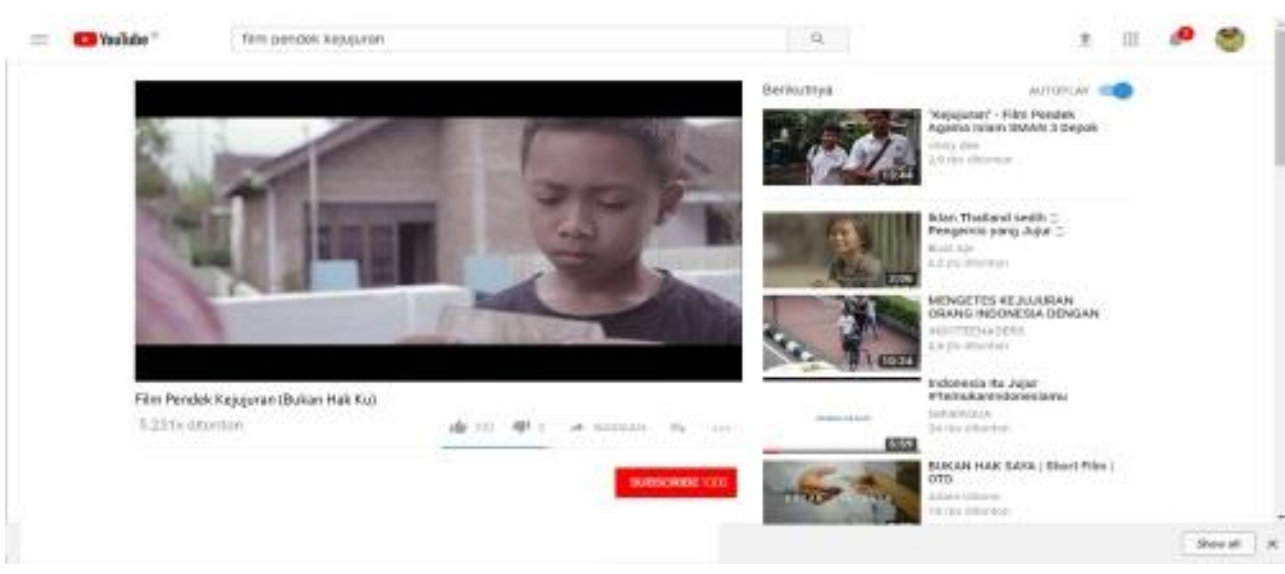

Gambar 7. Pengimplementasian di media sosial.

[Sumber: Dokumentasi penulis]

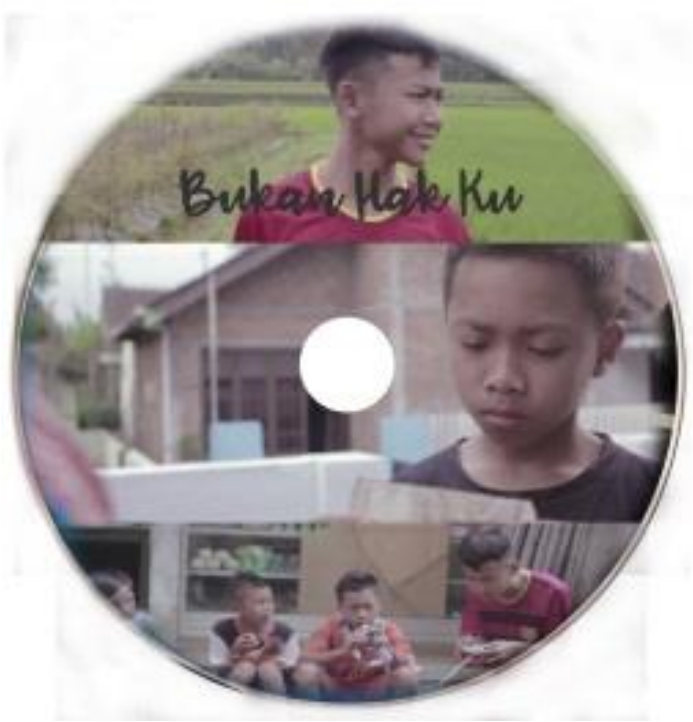

Gambar 8. Pengimplementasian compact disc.

[Sumber: Dokumentasi penulis]

Pada tahap pengujian dilakukan screening bersama 58 siswa SDN Cebongan 3, 2 orang tua yang memiliki anak usia 8-12 tahun, dan perwakilan Dinas Pendidikan Pemuda dan Olahraga Kota Salatiga. Berdasarkan hasil pengujian terhadap siswa SD tersebut, anakanak usia 8-12 tahun dapat memahami film dan mengerti isi pesan yang terdapat dalam film tersebut. Sedangkan menurut orang tua, mereka mengerti seharusnya anak 
diberikan dukungan ataupun reward ketika sudah berkata jujur dan benar dalam melakukan suatu hal, bukanya memarahi dan memungkirinya. Orang tua juga menjadi paham tentang peran keluarga dalam menanamkan kejujuran pada anak-anaknya. Sedangkan menurut hasil wawancara kepada Kepala Dinas Pendidikan Pemuda dan Olahraga Kota Salatiga, media pengajaran dalam bentuk film dapat menjadi salah satu alternatif bagi pengajar maupun proses pendidikan dalam menanamkan kejujuran pada anak usia 8-12 tahun. Film pendek ini juga dapat menjadi media pembelajaran baru sehingga tidak hanya bergantung pada buku pelajaran saja.

\section{KESIMPULAN}

Berdasarkan hasil perancangan dan pengujian yang telah dilakukan, didapatkan bahwa perancangan film pendek kejujuran untuk anak usia 8-12 tahun dengan judul "Bukan Hak-Ku" dinilai dapat menyampaikan informasi yang dimaksud dalam film tersebut. Bagi anak, orang tua, dan Dinas Pendidikan Pemuda dan Olahraga Kota Salatiga, film pendek tersebut dapat membantu dalam media pembelajaran anak, sehingga penonton mendapat kesan baru dalam media pembelajaran melalui sebuah film pendek tersebut. Keselarasan alur cerita yang ditunjang oleh unsur-unsur sinematogfi dalam film pendek ini dapat menciptakan suasana menjadi lebih dramatis. Penekanan mengenai kejujuran pada bagian-bagian tertentu dari film serta pendampingan orang tua saat menonton film merupakan faktor-faktor pendukung sehingga anak usia 8-12 tahun dapat lebih memahami mengenai pentingnya kejujuran dalam kehidupan sehari-hari. Kedepannya, penelitian ini dapat dikembangkan tidak hanya untuk menanamkan nilai-nilai kejujuran tetapi juga pendidikan karakter lainnya.

\section{DAFTAR PUSTAKA}

Bachtiar, Chamdani Lukman. (2013). Media Pembelajaran Audio Visual Terhadap Pembelajaran Lompat Jauh Pada Siswa Kelas IV SDN Grobogan 04 Kabupaten Grobogan Tahun Ajaran 2012/2013.

Fred, Wibowo. (1997). Dasar-Dasar Program Televisi, Jakarta: Grasindo.

Heinich et.al. (2002). Media dan Fungsinya. Jakarta: Depkominfo.

Irawan, Fety. (2014). Pendidikan Pancasila dan Kewarganegaraan, Fakultas Keguruan dan Ilmu Pendidikan, Universitas Muhammadiyah Surakarta.

Noval. (2015). Metode Penelitian Kualitatif dan Kualitatif. Diakses 20 April 2017http://www.seputarpengetahuan.com/2015/02metode-penelititankualitatif-dan.html.

Nugroho, Ali \& Yeni.P,. (2006). Metode Pengembangan Sosial Emosional. Jakarta : Universitas Terbuka.

Purbolaksito, Dedy. (2014). Paper Jurnal Online Pola Komunikasi Keluarga Dalam Menanamkan Nilai-Nilai Pendidikan Karakter Anak (Studi Kualitatif Penerapan Pola Komunikasi Keluarga dalam Pendidikan Karakter Anak pada Keluarga Jawa di Kelurahan Sangkrah Kecamatan Pasar Kliwon Kota Surakarta).

Sarwono, Jonathan dan Harry Lubis. (2007). Metode Riset untuk Desain Komunikasi Visual. Yogyakarta: Andi. 
Sumarsih. (2013). Pendidikan Karakter Disiplin Dan Kejujuran Anak Pada Keluarga Polisi (Studi Kasus di Aspolres Sragen Mageru RT 03/RW II Sragen Tengah Kecamatan Sragen Kabupaten Sragen Tahun 2013).

Syaiful, Agil. (2015). Teknik Pembuatan dan Pengertian Storyboard. Diakses tanggal 29 Mei 2017, https://sites.google.com/site/elearningtp2010/media-3d/teknikpembuatan-storyboard-media-animasi-3d/pengertian-storyboard. 